\title{
The Extracellular Matrix and $\mathrm{Ca}^{2+}$ Signaling Mechanisms
}

\author{
S. FILIP ${ }^{1}$, J. MOKRÝ ${ }^{2}$, O. FOROSTYAK ${ }^{3}$, G. DAYANITHI ${ }^{4,5}$ \\ ${ }^{1}$ Department of Oncology and Radiotherapy, Faculty of Medicine, Charles University, Hradec \\ Kralove, Czech Republic, ${ }^{2}$ Department of Histology and Embryology, Faculty of Medicine, Charles \\ University, Hradec Kralove, Czech Republic, ${ }^{3}$ Department of Neurochemistry, Institute of \\ Experimental Medicine, Czech Academy of Sciences, Prague, Czech Republic, ${ }^{4}$ Department of \\ Pharmacology and Toxicology, Faculty of Medicine, Charles University, Pilsen, Czech Republic, \\ ${ }^{5}$ Unité de recherche U1198, Institut National de la Santé et de la Recherche Médicale, Université de \\ Montpellier, Montpellier, France and Ecole Pratique des Hautes Etudes - Sorbonne, Paris, France
}

Received November 13, 2018

Accepted November 27, 2018

Epub Ahead of Print January 10, 2019

\section{Summary}

The extracellular matrix (ECM) consists of proteins, glycosaminoglycans and glycoproteins, that support the dynamic interactions between cells, including intercellular communication, cell attachment, cell differentiation, cell growth and migration. As such, the ECM represents an essential and very sensitive system within the tissue microenvironment that is involved in processes such as tissue regeneration and carcinogenesis. The aim of the present review is to evaluate its diversity through $\mathrm{Ca}^{2+}$ signaling and its role in muscle cell function. Here, we discuss some methodological approaches dissecting $\mathrm{Ca}^{2+}$ handling mechanisms in myogenic and non-myogenic cells, e.g. the importance of $\mathrm{Ca}^{2+}$ and calpains in muscle dystrophy. We also consider the reconstruction of skeletal muscle by colonization of decellularized ECM with muscle-derived cells isolated from skeletal muscle. Therefore, it is necessary to establish new methodological procedures based on $\mathrm{Ca}^{2+}$ signaling in skeletal muscle cells and their effect on ECM homeostasis, allowing the monitoring of skeletal muscle reconstruction and organ repair.

\section{Key words}

Extracellular matrix $\bullet \mathrm{Ca}^{2+}$ signaling $\bullet$ Homeostasis $\bullet$ Skeletal muscles $\bullet$ Muscle remodeling

\section{Corresponding author}

S. Filip, Charles University, Faculty of Medicine, Dept. of Oncology and Radiotherapy, Sokolská 548, 50005 Hradec Králové, Czech Republic. E-mail: filip@fnhk.cz

\section{Introduction}

Stem cells (SCs) are present in all tissue types, giving the origin to different cell lineages or performing tissue repair, among other functions; in this sense, the skeletal muscle is no exception. Muscle regeneration is mainly performed by satellite cells located on the surface of muscle fibers, just under the basal lamina. A satellite cell is frequently considered as a progenitor cell due to its unipotency; however, the engraftment capacity of isolated satellite cells into injured skeletal muscle is rather poor (Asakura et al. 2007, Mu et al. 2011) whereas cells from other sources, e.g. mesoangioblasts (Sampaloesi et al. 2006) and pericytes (Dellavalle et al. 2007, Birbrair et al. 2013) engraft into muscle fibers with a greater efficacy. Furthermore, the population of satellite cells is highly heterogeneous, some are derived from dermatomyotomes, others from prechordal mesoderm or several other possible sources. As a result, a minor subpopulation of satellite cells may include myogenic stem cells. For example, on the basis of different adhesive properties of cells Urish et al. (2005) separated a specific satellite cell population that is more resistant to oxidative stress. On the other hand, Tanaka et al. (2009) were able to isolate a rare side population subset of muscle cells characterized by the co-expression of ABCG2, Syndecan4 and Pax7. These cells occupied the satellite cell niche and exhibited a more robust stemness potential than previously 
characterized muscle progenitor cells, because these cells were capable of repopulating $75 \%$ of mature myofibers after transplantation (Tanaka et al. 2009). The identification of muscle-derived SCs has been complicated because several other cell types exhibit myogenic potential, i.e. interstitial muscle cells, mesenchymal stromal cells, pericytes, mesoangioblasts and hematopoietic SCs (which contribute to muscle regeneration through myelomonocytic precursors). In addition, myogenic cells can be also obtained from non-myogenic tissues, including brain, kidney, lung, thymus, intestine, synovial membrane, etc. (for review see Zammit et al. 2006).

Tissue injury is known to dysregulate well-balanced factors and feedback control mechanisms of the affected area, not only at homeostasis level but also at organ and system levels, with some events occurring at the level of the entire organism as well. Therefore, the response for tissue injury is complex and involves not only local factors (SCs activation, paracrine signaling, proliferation of adjacent cells, changes in niche structure and tissue vascularization, inflammatory cells infiltration, recruitment of new cells, etc.) but also a systemic response (immune response, cell mobilization, endocrine signaling, stress, changes in metabolism, etc.). However, the extent of these events depends largely on injury degree. A key factor involved in the negative control of skeletal muscle homeostasis and the maintenance of muscle size was identified as a member of the TGF- $\alpha$ family, myostatin. This factor, also known as growth and differentiation factor 8 (GDF8), is secreted from myocytes and negatively regulates the generation of new muscle cells (for review see Bradley et al. 2008). Moreover, myostatin binds and activates a complex formed by the Acvr2b receptor and ALK4 or ALK5 proteins, which is expressed by muscle SCs and proliferating myoblasts, thus inhibiting the expression of muscle regulatory factors and preventing satellite cell activation, myoblast proliferation and myogenesis. Through an autoregulatory loop, myostatin represses its own transcription and degrades the myostatin/Acvr2b complex. Moreover, myostatin signaling prolongs the survival of muscle fibers via the p53 pathway and stabilizes motor end-plates. The muscle regulatory factors (including MyoD), expressed during myocyte maturation, support myostatin gene transcription; although the bioavailability of the active myostatin homodimer is tightly controlled by multiple factors, e.g. through the expression of its extracellular antagonist, follistatin. The well-orchestrated interplay between developing and maturing cells creates a careful balance of muscle homeostasis that is optimal for muscular function and also allows its rapid regeneration in the case of injury; although it is known that loss-of-function mutations of the $G D F 8$ gene can alter this delicate balance, resulting in a highly increased number and size of myocytes (JouliaEkaza et al. 2006).

The aim of this review is to describe how the activation of $\mathrm{Ca}^{2+}$ signals have been adapted to control different muscle cell (MCs) function, elaborating on $\mathrm{Ca}^{2+}$ homeostasis and clearance mechanisms in myogenic and non-myogenic cells.

Excitation-contraction coupling in MCs mainly occurs through the activation of $\mathrm{Ca}^{2+}$ signaling cascades and the release of $\mathrm{Ca}^{2+}$ from intracellular stores (sarco/endoplasmic reticulum), involving respective IP3 receptors and ryanodine receptors (RyR). These RyR apparently have a greater modulatory function in smooth muscles or cultured skeletal muscle cells, whereas in adult skeletal muscle cells the IP3R play a modulatory role while RyR represent the major pathway for $\mathrm{Ca}^{2+}$ release from the sarcoplasmic reticulum (SR). Furthermore, RyR in cultured skeletal muscles become the dominant part of the triad together with SR and T-tubules. Though it is well known how $\mathrm{Ca}^{2+}$ signaling is activated under normal physiological conditions, it is yet to be clarified how $\mathrm{Ca}^{2+}$ signaling is activated after the transplantation of MCs. Since membrane depolarization is a key element for this activation, a greater attention will be paid to the mechanisms responsible for this event.

However, there are other circumstances where the activation of MCs depends upon the periodic release of $\mathrm{Ca}^{2+}$ from internal stores. Therefore, innovative methodological procedures based on monitoring of $\mathrm{Ca}^{2+}$ signaling mechanisms in skeletal muscle cells and their effect on ECM homeostasis need to be developed, perhaps providing a new avenue into the reconstruction of skeletal muscle and other organs.

\section{Extracellular matrix}

The components of the extracellular matrix (ECM) include basal laminas, connective tissue fibers, multi-adhesive glycoproteins, and proteoglycans, that play a key role in maintaining the structural integrity of tissues and organs. The ECM allows cell adhesion and regulates cell behavior through binding cell membrane receptors (e.g. integrins), bioactive growth factors, and 
altering local tissue stiffness (Calve and Simon, 2012). Therefore, the ECM plays an important role in maintaining the structural features of skeletal muscle. The ECM also provides a framework for the cells, contributes to tissue elasticity, and plays a role in directing the functions of residing cells. Recently, aging has been associated with pathogenic ECM architecture and increased muscle stiffness. These age-related alterations in the ECM induce a pathogenic fibroblast phenotype via YAP-TAZ signaling that directs muscle cell differentiation into a fibrogenic instead of myogenic lineage (Stearns-Reider et al. 2017), thus suggesting the ECM as a novel therapeutic target in the treatment of muscular degeneration.

The assembly of ECM components in mammalian organs is highly ordered, while currently available artificial scaffolds and constructs can hardly mimic the complexity of biological systems. However, decellularization procedures allow to obtain a biostroma, which retains organ microstructure and original composition of structural and bioactive molecules supporting cell attachment and organization. Although acellular scaffolds are immunologically inert and maintain organ shape and size, they can support cellular regeneration only to a certain extent after the transplantation because of the lack of viable cells; however, scaffolds precoated with living cells have improved integration capacity into the recipient tissues. Recently, several groups have confirmed this concept by the utilization of decellularized bioscaffolds reseeded with cells in the tissue engineering of complex bioartificial organs such as the heart (Ott et al. 2008), lung (Petersen et al. 2010), or liver (Uygun et al. 2010), which are fully functional and transplantable.

\section{Skeletal muscles}

Skeletal muscles that have been lost due to severe injury could be replaced by autografts during reconstruction surgery; however, the availability of suitable tissue for these autografts is severely limited. This pitfall could be overcome by the construction of artificial muscles created by the colonization of decellularized muscles with suitable cells, which shares much in common with isotransplants of entire muscles (e.g. extensor digitorum muscle) and show an excellent muscle reconstitution after the transplantation in recipients (Čížková et al. 2009a). Nevertheless, we have previously demonstrated that the basal laminas and satellite cells are left intact in isotransplanted tissues and that they are capable of initiating myogenesis accompanied by vascularization, innervation, and restoration of the muscle sensory reception, including the formation of muscle spindles (Č́žzová et al. 2009a,b). Earlier approaches to reconstructive surgery exploited tube-like components of acellular muscle as a scaffold, promoting axonal regrowth after spinal cord hemidissection to bridge a gap in sciatic nerve defects or to fill missing tissue in muscle defects (Arai et al. 2000, Fansa et al. 2001). Recently, a preparation of acellular muscle grafts has been optimized (Gillies et al. 2011), and their reseeding with myoblasts gave rise to engineered muscle constructs with histomorphological characteristics resembling native muscle which, under in vitro conditions, were capable of generating contractile force (Borschel et al. 2004, Valentin et al. 2010). Furthermore, we have demonstrated that high doses of whole-body irradiation also induce myeloablation and chimerism in tissues, and the entry of transplanted cells into the small intestine and liver (Filip et al. 2014). However, other functional characteristics of these grafts reoccupied with myogenic and non-myogenic cells after implantation have yet to be determined in animal models.

\section{Role of intracellular $\mathrm{Ca}^{2+}$}

$\mathrm{Ca}^{2+}$ is a ubiquitous intracellular messenger controlling a diverse range of cellular processes, such as gene transcription, muscle contraction and cell proliferation. The ability of such a simple ion to play a pivotal role in cell biology results from the ease with which cells shape $\mathrm{Ca}^{2+}$ signals in space, time and amplitude (Ludwig et al. 2002, Toescu and Dayanithi 2012, Dayanithi and Verkhartsky 2016, Forostyak et al. 2016). To generate and interpret this variety of $\mathrm{Ca}^{2+}$ signals, different cell types employ diverse components selected from a $\mathrm{Ca}^{2+}$ signaling "toolkit", which comprises an array of homeostatic mechanisms (Toescu and Dayanithi 2012, Forostyak et al. 2013). By mixing and matching components from this toolkit, the cells can obtain $\mathrm{Ca}^{2+}$ signals that are appropriate to their physiology and pharmacology (Berridge 2008). The increment levels of $\left[\mathrm{Ca}^{2+}\right]_{i}$ within a cell is finely modulated in terms of ion quantity, time and space, thus constituting a complex language that can only be interpreted by specific proteins (Viero et al. 2014). Recent studies have demonstrated the importance of local $\mathrm{Ca}^{2+}$ signals in defining the interaction specificity of $\mathrm{Ca}^{2+}$ 
with its targets. Thus, to understand the roles played by myogenic $\mathrm{Ca}^{2+}$ signaling we must first consider: 1) the triggers and targets within these signaling domains; 2) interdomain signaling, and 3) how these $\mathrm{Ca}^{2+}$ signals integrate with other signaling networks involved in myogenesis (Pubill et al. 2001, Dayanithi et al. 2012). Currently available imaging techniques that provide direct visualization and evaluation of these $\mathrm{Ca}^{2+}$ signals have also been described (Dayamithi et al. 2012, Forostyak et al. 2013), including stem cells of various origins (Dayanithi and Verkhratsky 2016).

\section{$\mathrm{Ca}^{2+}$ homeostasis in muscle cells}

\section{During muscle fibrillation, intracellular} $\mathrm{Ca}^{2+}$ signaling changes substantially in myocytes/myotubes. This remodeled intracellular $\mathrm{Ca}^{2+}$ homeostasis plays an important role in the development of contractile dysfunction and the changes in cellular electrophysiology (contractile and electrical remodeling). Moreover, unstable intracellular $\mathrm{Ca}^{2+}$ signaling (i.e. increased $\mathrm{Ca}^{2+}$ sparks and $\mathrm{Ca}^{2+}$ waves) has been observed in mammalian striated muscle cells, cardiac myocytes, and skeletal muscle cells in culture, in association with genetic disorders. Therefore, the identification of novel targets counteracting or preventing $\mathrm{Ca}^{2+}$ signaling is an important part of skeletal muscle research. In this regard, it would be critical to evaluate the properties of 1) $\mathrm{Ca}^{2+}$ overload, 2) remodeling, and 3) steady state, as well as the distinct phases of "recovery" of intracellular $\mathrm{Ca}^{2+}$ handling: 4) $\mathrm{Ca}^{2+}$ unloading, 5) reverse remodeling, and 6) full recovery (Toescu and Dayanithi 2012). This would have the important implications concerning the timing and type of pharmacological intervention, particularly when dealing with new compounds aimed at intracellular $\mathrm{Ca}^{2+}$ stabilization (Leuranguer et al. 2000, Dayanithi et al. 2012).

\section{$\mathrm{Ca}^{2+}$ signaling}

$\mathrm{Ca}^{2+}$ concentration inside the cells is tightly regulated by a series of mechanisms, some of which have been extensively studied in muscle cells e.g. schematic drawings of the possible $\mathrm{Ca}^{2+}$ clearance mechanisms in myogenic and non-myogenic cells (Fig. 1). This is the case of the store-operated $\mathrm{Ca}^{2+}$ entry, mitochondrial $\mathrm{Ca}^{2+}$ uptake, and the IP3 cascade. These processes were recently described in skeletal muscle cells. The "store- operated $\mathrm{Ca}^{2+}$ entry" allows storage refilling after muscle fiber depolarization, which can also be activated after partial depletion of the SR (Troadec et al. 1998, Boccara et al. 1999, Pubill et al. 2001, Dayanithi et al. 2012). Mitochondrial $\mathrm{Ca}^{2+}$ uptake accelerates muscle relaxation and allows the adaptation of the ATP supply to the increased energy demand. On the other hand, IP3 receptors are found in the nuclear envelope and are involved in $\mathrm{Ca}^{2+}$ waves propagating from one nucleus to another. How this $\mathrm{Ca}^{2+}$ entry affects the local concentration of $\mathrm{Ca}^{2+}$ in subcellular compartments and whether this process is involved in physiological functions, such as regeneration and development, is still unclear.

Furthermore, myoblast fusion is also a critical process contributing to muscle growth during development and to myofiber regeneration after the injury, for which the myoblasts fuse with each other as well as with multinucleated myotubes in order to enlarge the myofiber. Earlier studies demonstrated that myoblast fusion requires extracellular $\mathrm{Ca}^{2+}$ as well as changes in cell membrane topography and cytoskeletal organization (Pubill et al. 2001). Other recent studies have identified several cell-surface and intracellular proteins mediating myoblast fusion through $\mathrm{Ca}^{2+}$ signaling. Moreover, emerging evidence suggests that myoblast fusion is also regulated by the activation of specific signaling pathways leading to the expression of genes essential for the occurrence of this fusion and for modulating cytoskeletal rearrangement (Pubill et al. 2001, Dayanithi et al. 2009, Dayanithi and Verkhratsky 2016).

\section{Skeletal muscle dystrophy and the role of calpain 3}

Calpains are a family of $\mathrm{Ca}^{2+}$-dependent cysteine proteases (for review see Croall and DeMartino 1991, Carafoli and Molinari 1998, Goll et al. 2003), the members of which are expressed ubiquitously (calpains 1 and 2) or in a tissue-specific way (calpain 3 is skeletal muscle specific and an isoform of calpain 3 was found in the lens). It was shown that in addition to $\mathrm{Ca}^{2+}$ ions, the activation of calpains is also modulated by the association with a $30 \mathrm{kD}$ small subunit or to membranes, by the autolysis of N-terminus or by an inhibitor (calpastatin). The activation and concentration of the calpains were found to be increased in the mouse model of Duchenne muscular dystrophy (mdx mice). The protein degradation 

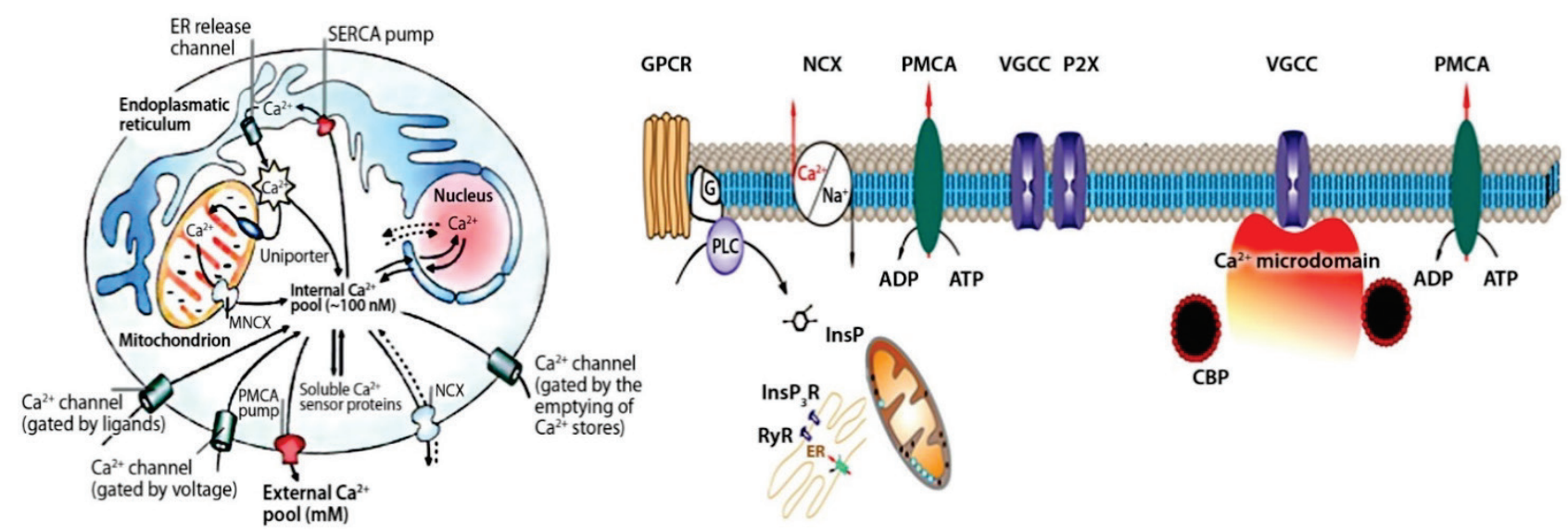

Fig. 1. Methodological approach to dissect the possible $\mathrm{Ca}^{2+}$ clearance mechanisms in myogenic and non-myogenic cells. GPCR: G-protein coupled receptor; NCX: $\mathrm{Na}^{+} / \mathrm{Ca}^{2+}$ exchanger; MNCX: mitochondrial $\mathrm{Na}^{+} / \mathrm{Ca}^{2+}$ exchanger; PMCA: plasma membrane $\mathrm{Ca}^{2+}$-ATPase; VGCC: voltage-gated $\mathrm{Ca}^{2+}$ channels; P2X; purinoreceptor P2X; InsP ${ }_{3} \mathrm{R}$ : inositol 1,4,5-trisphosphate receptor; RyR: ryanodine receptor; ER: endoplasmic reticulum; $\mathrm{CBP}$ : $\mathrm{Ca}^{2+}$-binding protein; PLC: phospholipase $\mathrm{C}$. $\mathrm{Ca}^{2+}$ signals in the terminals are triggered by $\mathrm{Ca}^{2+}$ entry through VGCC (probably L-type), effective $\mathrm{Ca}^{2+}$ buffering by CBP; powerful $\mathrm{Ca}^{2+}$ extrusion by PMCAs, which are assisted by mitochondria at high $\mathrm{Ca}^{2+}$ loads; $\mathrm{Ca}^{2+}$ signals are generated by both plasmalemmal $\mathrm{Ca}^{2+}$ entry and intracellular $\mathrm{Ca}^{2+}$ release via activation of RyR/InsP ${ }_{3} \mathrm{R}$, whereas the reduction of $\left[\mathrm{Ca}^{2+}\right]$ i transients is accomplished by the combined action of plasmalemmal and intracellular $\mathrm{Ca}^{2+}$ pumps, $\mathrm{NCX}$ and mitochondrial $\mathrm{Ca}^{2+}$ uptake. These $\mathrm{Ca}^{2+}$-clearance mechanisms could be evaluated by subjecting the cells under i) $\mathrm{Ca}^{2+} / \mathrm{Na}^{+}$-free conditions ( $\mathrm{PM} \mathrm{Ca}{ }^{2+}$ pump), ii) Lanthanum, $\mathrm{L}^{3+}\left(\mathrm{PM} \mathrm{Na}^{+} / \mathrm{Ca}^{2+}\right.$ exchanger), thapsigargin (TG), cyclopiazonic acid (CPA: $\mathrm{Ca}^{2+}$-ATPase inhibitors), caffeine and ryanodine (SERCA); CCCP-carbonyl cyanide 3-chlorophenylhydrazone (inhibitor of mitochondrial $\mathrm{Ca}^{2+}$ uptake) and FCCP; immunocytochemical analysis (cytoplasmic $\mathrm{Ca}^{2+}$-binding proteins). TG and CPA can be used to analyze the role of intracellular $\mathrm{Ca}^{2+}$ stores (IP3; ER/SR). Methods for evaluating the mitochondrial role in the induction of apoptosis can be also analyzed using buffering of $\left[\mathrm{Ca}^{2+}\right] \mathrm{c}\left(\mathrm{Ca}^{2+}\right.$ chelators: BAPTA, EGTA), analysis of driving force of mitochondrial $\mathrm{Ca}^{2+}$ uptake (FCCP, CCCP), and inhibition of the mitochondrial uptake sites (Ruthenium Red and RU360).

was enhanced in mdx muscle (Turner et al. 1988), suggesting that increased degradation resulted from the elevated $\mathrm{Ca}^{2+}$ levels existing within the dystrophic muscle. The known substrates of calpains are the membrane-associated cytoskeletal proteins, the plasma membrane (PM) $\mathrm{Ca}^{2+}$-ATPase and the ion channel proteins. Other studies demonstrated that the $\mathrm{Ca}^{2+}$ pump located in the PM is a preferred substrate of calpain in erythrocytes (Salamino et al. 1994). It has also been shown that the calpains in normal tissues exert regulatory roles including in dystrophic process by affecting the metabolic pathway and cleave substrates at restricted locations (Carafoli and Molinari 1998). This evidence supports the important role for pathologically high calpain activity in muscular dystrophy through disruption of specific regulatory mechanisms in muscles. In earlier studies using primary culture of mouse skeletal muscle from calpain 3-deficient (capn3 -/-) mice (which are fully fertile and viable, and showed a mild muscular dystrophy that affects a specific group of muscles) it was shown that affected muscles manifest a similar apoptosis-associated perturbation of the I $\mathrm{KB} \alpha / \mathrm{NF} \kappa \mathrm{B}$ pathway as seen in LGMD2A patients (Baghdiguian et al. 1999) and capn3 -/- mice (Richard et al. 2000).

\section{Calpain 3 knock-out mice as a model to study the muscle dystrophy and role of $\left[\mathrm{Ca}^{2+}\right]_{\mathbf{i}}$}

Using the primary cultures of skeletal muscle cells from normal and capn 3 -/- mice it was demonstrated the upstream and downstream events occurring during pharmacologically-induced $\left[\mathrm{Ca}^{2+}\right]_{\mathrm{i}}$ rise in myoblasts and myotubes from normal and capn3 -/- mice (Dayanithi et al. 2009). Here, calpain 3 acts as a feedback regulator for $\mathrm{Ca}^{2+}$ homeostasis in skeletal muscle cells by exerting its action on RyR. The latter, also known as $\mathrm{Ca}^{2+}$ release channel, is a key protein involved in excitationcontraction coupling. Its activity is regulated by a $94 \mathrm{kDa}$ thiol-protease of the junctional SR membranes which specifically cleaves one site on the RyR. This cleavage results in enhancement of $\mathrm{Ca}^{2+}$ efflux from SR vesicles (Shoshan-Barmatz et al. 1994, Schevchenko et al. 1998).

\section{Role of intracellular $\mathrm{Ca}^{2+}$ stores in muscle dystrophy}

Muscular dystrophies represent a heterogeneous group of severe degenerative disorders characterized by progressive muscle fiber weakness, degeneration, and 
death. These changes derive from genetic mutations affecting either membrane, cytoplasmic, nuclear or ECM proteins essential for muscle function, therefore turning them into a clinically, genetically and biochemically heterogeneous group. Past and current research into the mechanisms and therapeutic approaches for muscular dystrophies have extensively been developed, encompassing a wide range of strategies such as cellular and stem cell therapies, gene engineering, and various pharmacological approaches.

Of interest, calpains are not completely responsible for this RyR cleavage in both normal and calpain 3-deficient skeletal muscles. The cleavage of RyR in the absence of calpain 3 could be due to calpain $1 \mathrm{and} /$ or 2 which are widely expressed in all cell types. The activity of these calpains could be redundant in that case (Dayanithi et al. 2009). To assess the activity of ryanodine-sensitive internal $\mathrm{Ca}^{2+}$ stores, caffeine stimulation was used to activate RyR (Wang et al. 2003). The effectiveness of caffeine in normal myotubes in comparison to myoblasts indicated a maturation of a proper RyR signaling in culture during the fusion process. These results indicated that both myoblasts and myotubes from capn3 -/- mice displayed weaker amplitudes of the caffeine-induced $\left[\mathrm{Ca}^{2+}\right]_{\mathrm{i}}$ transients than in normal cells, which could indicate a lower $\mathrm{SR} \mathrm{Ca}^{2+}$ loading state in capn3 -/- skeletal cells, a decreased number of RyR at the SR membrane surface, or a decreased sensitivity of these receptors, but these alterations are independent of any cleavage by calpain 3 (Dayanithi et al. 2009). In the above study, cyclopiazonic acid (CPA), a compound that depletes internal $\mathrm{Ca}^{2+}$ stores (Dayanithi et al. 2009), evoked increases of $\left[\mathrm{Ca}^{2+}\right]_{\mathrm{i}}$ rise in all conditions tested. However, these responses were weaker in capn3 -/- myotubes in comparison to wild-type myotubes, reinforcing the hypothesis that SR $\mathrm{Ca}^{2+}$ loading was decreased in capn3 -/- myotubes or indicating that SR $\mathrm{Ca}^{2+}$-ATPases were less expressed or less sensitive to the blocker in capn 3 -/- myotubes. The difference in CPA responses between wild-type myoblasts and myotubes is most likely due to a change in the size of the SR that correlates a change in the size of the cells during fusion in culture, myotubes having a wider area.

Furthermore, caffeine is thought to directly activate RyR at the SR membrane, leading to the opening of this channel and the release of $\mathrm{Ca}^{2+}$ from the SR into the cytosol, independently of any $\mathrm{Ca}^{2+}$ influx through the plasma membrane. The fact that low extracellular $\mathrm{Ca}^{2+}$ and blockers of L-type $\mathrm{Ca}^{2+}$ channels abolished caffeineinduced $\left[\mathrm{Ca}^{2+}\right]_{i}$ increases in capn3 -/- myotubes, suggesting that RyR opening and $\mathrm{SR} \mathrm{Ca}^{2+}$ release lead to a $\mathrm{Ca}^{2+}$ influx through L-type $\mathrm{Ca}^{2+}$ channels solely in the capn3 -/- myotubes (Boccara et al. 1999). Since cytosolic $\mathrm{Ca}^{2+}$ is known to negatively regulate these channels (inactivation) and that the release from the SR is not sufficient to evoke a depolarization enabling the opening of L-type $\mathrm{Ca}^{2+}$ channels (Vandael et al. 2010), it is most likely that an additional channel at the PM induces a depolarization in response to the caffeine-evoked $\left[\mathrm{Ca}^{2+}\right]_{\mathrm{i}}$ increases in capn3 -/- myotubes.

\section{Dystrophic skeletal muscle fibers and deficient $\mathrm{Ca}^{2+}$ regulation}

Another type of channel activated by the depletion of the SR is the store-operated channel (SOC) (Ma and Pan 2003, Launikonis and Rios 2007). It has been shown in dystrophic skeletal muscle fibers that PLA2 was responsible for an increase in SOC-dependent $\mathrm{Ca}^{2+}$ entry (Boittin et al. 2006), suggesting that in the absence of calpain 3, the activity or the expression of SOC was increased and was mediated by a PLA2-dependent mechanism. This phenomenon leads to the opening of L-type $\mathrm{Ca}^{2+}$ channels subsequently to $\mathrm{SR} \mathrm{Ca}^{2+}$ release. In turn, since L-type $\mathrm{Ca}^{2+}$ channels and RyR are physically and functionally coupled in skeletal muscle cells, the enhanced activity of SOC in capn3 -/myotubes might induce an additional $\mathrm{Ca}^{2+}$ release from SR and thus depletion of the SR, which could account for the dystrophic behavior of diseased skeletal muscle fibers. Furthermore, the reduced SR content might account for small $\mathrm{Ca}^{2+}$ signals consequently to RyR activation by caffeine. Another possibility would be that the lack of calpain 3 leads to a decrease of RyR sensitivity to caffeine, probably involving a regulation of the post-translational maturation of the receptor, which is independent of any functional cleavage of RyR (Dayanithi et al. 2009). RyR contains many endogenous cysteines in the cytoplasmic domain of the protein and hence the binding of caffeine to its site of the cytosolic face of RyR would require an activation of RyR by extracellular $\mathrm{Ca}^{2+}$ signals in order to induce the proper opening of the receptor. It was concluded that one could induce a skeletal muscle dystrophy in mice due to the absence of calpain 3, and thus draw a general picture of the cellular pathways involved in this disease. Thus, the LGMD2A dystrophy has been characterized by 
a dysregulation of the $I \kappa \mathrm{B} \alpha / \mathrm{NF}-\kappa \mathrm{B}$ pathway leading to apoptosis (Benayoun et al. 2008), an increase of membrane permeability, a decrease of SR activity, a decrease of the size of the SR and a dysfunction of RyR signaling.

\section{Conclusions and future directions}

Detailed knowledge of intracellular $\mathrm{Ca}^{2+}$ signaling cascades gained in recent years by analyzing muscle cell response after the exposure to activators or blockers of different types of calcium channels with a fast fluorescence microspectrofluorimetry enabled to characterize not only distinct cell types present in the skeletal muscle but also to distinguish distinct physiological statuses of the similar cell phenotype. Such detailed characteristics could allow assessing the actual cell quality as $\mathrm{Ca}^{2+}$ signaling reflects pathophysiological conditions to which muscle cells are exposed in vitro and in vivo.

Excitation-contraction coupling in skeletal muscle cells occurs mainly through the activation of $\mathrm{Ca}^{2+}$ signaling cascades and the release of $\mathrm{Ca}^{2+}$ from intracellular stores (IP3/ryanodine) involving respective IP3 and ryanodine receptors. Since the latter appears to have a greater modulatory function, most attention could be focused on how $\mathrm{Ca}^{2+}$ signaling is activated in muscle cells under normal physiological conditions and after the transplantation. A thorough knowledge on homeostatic calcium mechanisms could be helpful for the evaluation of regenerative capacity of progenitor or stem cells and the prediction of the cell fate, which could be crucial especially if such cells were considered as suitable candidates for cell-based therapy or seeding acellular scaffolds for tissue-engineered muscle constructs. Elimination of the cells showing features of $\mathrm{Ca}^{2+}$ signaling dysregulation and careful selection of healthy cells should be considered as a reliable way for predicting the efficacy of such muscle treatment in terms of a longterm cell survival. Further refinement and new insights in the underlying mechanisms could be obtained in the near future from the experiments based on the usage of genetically encoded calcium indicators and from the analysis of the changes in calcium homeostasis by fluorescent ratiometric biosensors in live cell imaging (Horikawa 2015, Snell et al. 2018).

\section{Conflict of Interest}

The authors have no conflict of interest regarding the content of this article.

\section{Acknowledgements}

This work was supported by grant GACR No 15-09161S and PROGRES Q40/06. The authors wish to thank Dr. Daniel Díaz, Ph.D. for his kind assistance in English language revision and proofreading.

\begin{abstract}
Abbreviations
ABCG2 - protein, ATP-binding cassette subfamily G member 2; Acvr2b - activin receptor type-2B; ALK4 activin-like kinase 4; ALK5 - activin-like kinase 5; ATP - adenosine triphosphate; CPA - cyclopiazonic acid; ECM - extracellular matrix; GDF8 - myostatin, growth differentiation factor 8; IP3 - inositol 1,4,5-trisphosphate; IP3R - inositol 1,4,5-trisphosphate receptors; LGMD2A - limb-girdle muscular dystrophy type 2A; MCs - muscle cells; MyoD - protein, muscle differentiation; Pax7 paired box protein 7; p53 - tumor protein p53; PLA2 phospholipase A2; RyR - ryanodine receptors; SCs stem cells; SOC - store-operated channel; SR sarcoplasmatic reticulum; Syndecan 4 - protein 4 , single transmembrane domain protein; TGF- $\alpha$ - transforming growth factor $\alpha$; YAP-TAZ - transcription factors, signaling pathway.
\end{abstract}

\section{References}

ARAI T, KANJE M, LUNDBORG G, SONDELL M, LIU XL, DAHLIN LB: Axonal outgrowth in muscle grafts made acellular by chemical extraction. Restor Neurol Neurosci 17: 165-174, 2000.

ASAKURA A, HIRAI H, KABLAR B, MORITA S, ISHIBASHI J, PIRAS BA, CHRIST AJ, VERMA M, VINERETSKY KA, RUDNICKI MA: Increased survival of muscle stem cells lacking the MyoD gene after transplantation into regenerating skeletal muscle. Proc Natl Acad Sci USA 104: 16552-16557, 2007.

BAGHDIGUIAN S, MARTIN M, RICHARD I, PONS F, ASTIER C, BOURG N, HAY RT, CHEMALY R, HALABY G, LOISELET J, ANDERSON LV, LOPEZ DE MUNAIN A, FARDEAU M, MANGEAT P, BECKMANN JS, LEFRANC G: Calpain 3 deficiency is associated with myonuclear apoptosis and profound perturbation of the IкB $\alpha / \mathrm{NF}-\kappa \mathrm{B}$ pathway in limb-girdle muscular dystrophy type 2A. Nat Med 5: 503-511, 1999. 
BENAYOUN B, BAGHDIGUIAN S, LAJMANOVICH A, BARTOLI M, DANIELE N, GICQUEL E, BOURG N, RAYNAUD F, PASQUIER MA, SUEL L, LOCHMULLER H, LEFRANC G, RICHARD I: NF-אB-dependent expression of the antiapoptotic factor c-FLIP is regulated by calpain 3, the protein involved in limb-girdle muscular dystrophy type 2A. FASEB J 22: 1521-1529, 2008.

BERRIDGE MJ: Smooth muscle cell calcium activation mechanisms. J Physiol (Lond) 586: 5047-5061, 2008.

BIRBRAIR A, ZHANG T, WANG ZM, MESSI ML, ENIKOLOPOV GN, MINTZ A, DELBONO O: Role of pericytes in skeletal muscle regeneration and fat accumulation. Stem Cells Dev 22: 2298-2314, 2013.

BOCCARA G, CHOBY C, FRAPIER JM, QUIGNARD JF, NARGEOT J, G DAYANITHI G, RICHARD S: Regulation of $\mathrm{Ca}^{2+}$ homeostasis by atypical $\mathrm{Na}^{+}$currents in cultured human coronary myocytes. Circ Res $\mathbf{8 5}$ : 606-613, 1999.

BOITTIN FX, PETERMANN O, HIRN C, MITTAUD P, DORCHIES OM, ROULET E, AND UT RUEGG UT: $\mathrm{Ca}^{2+}$-independent phospholipase A2 enhances store-operated $\mathrm{Ca}^{2+}$ entry in dystrophic skeletal muscle fibers. J Cell Sci 119: 3733-3742, 2006.

BORSCHEL GH, DENNIS RG, KUZON WM: Contractile skeletal muscle tissue-engineered on an acellular scaffold. Plast Reconstr Surg 113: 595-602, 2004.

BRADLEY L, YAWORSKY PJ, WALSH FS: Myostatin as a therapeutic target for musculoskeletal disease. Cell Mol Life Sci 65: 2119-2124, 2008.

CALVE S, SIMON HG: Biochemical and mechanical environment cooperatively regulate skeletal muscle regeneration. FASEB J 26: 2538-2545, 2012.

CARAFOLI E, MOLINARI M: Calpain: a protease in search of a function? Biochem Biophys Res Commun 247: 193-203, 1998.

ČÍŽKOVÁ D, SOUKUP T, MOKRÝ J: Nestin expression reflects formation, revascularization and reinnervation of new myofibers in regenerating rat hind limb skeletal muscles. Cells Tissues Organs 189: 338-347, 2009a.

ČÍŽKOVÁ D, SOUKUP T, MOKRÝ J: Expression of nestin, desmin and vimentin in intact and regenerating muscle spindles of rat hind limb skeletal muscles. Histochem Cell Biol 131: 197-206, $2009 \mathrm{~b}$.

CROALL DE, DEMARTINO GN: Calcium-activated neutral protease (calpain) system: structure, function, and regulation. Physiol Rev 71: 813-847, 1991.

DAYANITHI G, RICHARD I, VIERO C, MAZUC E, MALLIE S, VALMIER J, BOURG N, HERASSE M, MARTY I, LEFRANC G, MANGEAT P, BAGHDIGUIAN S: Alteration of sarcoplasmic reticulum $\mathrm{Ca}^{2+}$ release in skeletal muscle from calpain 3-deficient mice. Int J Cell Biol 2009: 340346, 2009.

DAYANITHI G, FOROSTYAK O, UETA Y, VERKHRATSKY A, TOESCU EC: Segregation of calcium signalling mechanisms in magnocellular neurones and terminals. Cell Calcium 51: 293-299, 2012.

DAYANITHI G, VERKHRATSKY A: Calcium signalling in stem cells: Molecular physiology and multiple roles. Cell Calcium 59: 55-56, 2016.

DELlaVALlE A, SAMPAOLESI M, TONLORENZI R, TAGLIAFICO E, SACCHETTI B, PERANI L, INNOCENZI A, GALVEZ BG, MESSINA G, MOROSETTI R, LI S, BELICCHI M, PERETTI G, CHAMBERLAIN JS, WRIGHT WE, TORRENTE Y, FERRARI S, BIANCO P, COSSU G: Pericytes of human skeletal muscle are myogenic precursors distinct from satellite cells. Nat Cell Biol 9: 255-267, 2007.

FANSA H, KEILHOFF G, WOLF G, SCHNEIDER W, GOLD BG: Tissue engineering of peripheral nerves: a comparison of venous and acellular muscle grafts with cultured schwann cells. Plast Reconstr Surg 107: 495-496, 2001.

FILIP S, MOKRÝ J, VÁVROVÁ J, SINKOROVÁ Z, MIČUDA S, SPONER P, FILIPOVÁ A, HREBÍKOVÁ H, DAYANITHI G: The peripheral chimerism of bone marrow-derived stem cells after transplantation: regeneration of gastrointestinal tissues in lethally irradiated mice. J Cell Mol Med 18: 832-843, 2014.

FOROSTYAK O, FOROSTYAK S, KORTUS S, SYKOVA E, VERKHRATSKY A, FOROSTYAK O, ROMANYUK N, VERKHRATSKY A, SYKOVA E, DAYANITHI G: Plasticity of calcium signaling cascades in human embryonic stem cell-derived neural precursors. Stem Cells Dev 22: 1506-1521, 2013.

FOROSTYAK O, BUTENKO O, ANDEROVA M, FOROSTYAK S, SYKOVA E, VERKHRATSKY A, DAYANITHI G: Specific profiles of ion channels and ionotropic receptors define adipose- and bone marrowderived stromal cells. Stem Cell Res 16: 622-634, 2016a. 
GILLIES AR, SMITH LR, LIEBER RL, VARGHESE S: Method for decellularizing skeletal muscle without detergents or proteolytic enzymes. Tissue Eng Part C Methods 17: 383-389, 2011.

GOLL DE, THOMPSON VF, LI H, WEI W, CONG J: The calpain system. Physiol Rev 83: 731-801, 2003.

HORIKAWA K: Recent progress in the development of genetically encoded $\mathrm{Ca}^{2+}$ indicators. J Med Invest 62: 24-28, 2015.

JOULIA-EKAZA D, DOMINIQUE JE, CABELLO G, GÉRARD C: Myostatin regulation of muscle development: molecular basis, natural mutations, physiopathological aspects. Exp Cell Res 312: 2401-2414, 2006.

LAUNIKONIS BS, RÍOS E: Store-operated $\mathrm{Ca}^{2+}$ entry during intracellular $\mathrm{Ca}^{2+}$ release in mammalian skeletal muscle. J Physiol (Lond) 583: 81-97, 2007.

LEURANGUER V, MONTEIL A, BOURINET E, DAYANITHI G, NARGEOT J: T-type calcium currents in rat cardiomyocytes during postnatal development: contribution to hormone secretion. Am J Physiol Heart Circ Physiol 279: H2540-H2548, 2000.

LUDWIG M, SABATIER N, BULL PM, LANDGRAF R, DAYANITHI G, LENG G: Intracellular calcium stores regulate activity-dependent neuropeptide release from dendrites. Nature 418: 85-89, 2002.

MA J, PAN Z: Retrograde activation of store-operated calcium channel. Cell Calcium 33: 375-384, 2003.

MU X, XIANG G, RATHBONE CR, PAN H, BELLAYR IH, WALTERS TJ, LI Y: Slow-adhering stem cells derived from injured skeletal muscle have improved regenerative capacity. Am J Pathol 179: 931-941, 2011.

OTT HC, MATTHIESEN TS, GOH SK, BLACK LD, KREN SM, NETOFF TI, TAYLOR DA: Perfusiondecellularized matrix: using nature's platform to engineer a bioartificial heart. Nat Med 14: 213-221, 2008.

PETERSEN TH, CALLE EA, ZHAO L, LEE EJ, GUI L, RAREDON MB, GAVRILOV K, YI T, ZHUANG ZW, BREUER C, HERZOG E, NIKLASON LE: Tissue-engineered lungs for in vivo implantation. Science 329: 538-541, 2010.

PUBILL D, DAYANITHI G, SIATKA C, ANDRÉS M, DUFOUR MN, GUILLON G, MENDRE C: ATP induces intracellular calcium increases and actin cytoskeleton disaggregation via P2x receptors. Cell Calcium 29: 299-309, 2001.

RICHARD I, ROUDAUT C, MARCHAND S, BAGHDIGUIAN S, HERASSE M, STOCKHOLM D, ONO Y, SUEL L, BOURG N, SORIMACHI H, LEFRANC G, FARDEAU A, SÉBILLE A, BECKMANN JS: Loss of calpain 3 proteolytic activity leads to muscular dystrophy and to apoptosis-associated $\mathrm{I} \kappa \mathrm{B} \alpha /$ nuclear factor $\kappa \mathrm{B}$ pathway perturbation in mice. J Cell Biol 151: 1583-1590, 2000.

SALAMINO F, SPARATORE B, MELLONI E, MICHETTI M, VIOTTI PL, PONTREMOLI S, CARAFOLI E: The plasma membrane calcium pump is the preferred calpain substrate within the erythrocyte. Cell Calcium 15: 28-35, 1994.

SAMPAOLESI M, BLOT S, D’ANTONA G, GRANGER N, TONLORENZI R, INNOCENZI A, MOGNOL P, THIBAUD JL, GALVEZ BG, BARTHÉLÉMY I, PERANI L, MANTERO S, GUTTINGER M, PANSARASA O, RINALDI C, CUSELLA-DE ANGELIS MG, TORRENTE Y, BORDIGNON C, BOTTINELLI R, COSSU G: Mesoangioblast stem cells ameliorate muscle function in dystrophic dogs. Nature 444: 574-579, 2006.

SHEVCHENKO S, FENG W, VARSANYI M, SHOSHAN-BARMATZ V: Identification, characterization and partial purification of a thiol-protease which cleaves specifically the skeletal muscle ryanodine receptor/Ca ${ }^{2+}$ release channel. J Membr Biol 161: 33-43, 1998.

SHOSHAN-BARMATZ V, WEIL S, MEYER H, VARSANYI M, HEILMEYER LM: Endogenous, Ca ${ }^{2+}$-dependent cysteine-protease cleaves specifically the ryanodine receptor $/ \mathrm{Ca}^{2+}$ release channel in skeletal muscle. $J$ Membr Biol 142: 281-288, 1994.

SNELL NE, RAO VP, SECKINGER KM, LIANG J, LESER J, MANCINI AE, RIZZO MA. Homotransfer of FRET reporters for live cell imaging. Biosensors 8: E89, 2018.

STEARNS-REIDER KM, D’AMORE A, BEEZHOLD K, ROTHRAUFF B, CAVALLI L, WAGNER WR, VORP DA, TSAMIS A, SHINDE S, ZHANG C, BARCHOWSKY A, RANDO TA, TUAN RS, AMBROSIO F: Aging of the skeletal muscle extracellular matrix drives a stem cell fibrogenic conversion. Aging Cell 16: 518-528, 2017. 
TANAKA KK, HALL JK, TROY AA, CORNELISON DDW, MAJKA SM, BB OLWIN BB: Syndecan-4-expressing muscle progenitor cells in the SP engraft as satellite cells during muscle regeneration. Cell Stem Cell 4: 217-225, 2009.

TOESCU EC, DAYANITHI G: Neuroendocrine signalling: natural variations on a $\mathrm{Ca}^{2+}$ theme. Cell Calcium 51: 207-211, 2011.

TROADEC JD, THIRION S, NICAISE G, LEMOS JR, DAYANITHI G: ATP-evoked increases in [Ca $\left.{ }^{2+}\right]$ i and peptide release from rat isolated neurohypophysial terminals via a P2X2 purinoceptor. J Physiol (Lond) 511: 89-103, 1998.

TURNER PR, WESTWOOD T, REGEN CM, STEINHARDT RA: Increased protein degradation results from elevated free calcium levels found in muscle from mdx mice. Nature 335: 735-738, 1988.

URISH K, KANDA Y, HUARD J: Initial failure in myoblast transplantation therapy has led the way toward the isolation of muscle stem cells: potential for tissue regeneration. Curr Top Dev Biol 68: 263-280, 2005.

UYGUN BE, SOTO-GUTIERREZ A, YAGI H, IZAMIS ML, GUZZARDI MA, SHULMAN C, MILWID J, KOBAYASHI N, TILLES A, BERTHIAUME F, HERTL M, NAHMIAS Y, YARMUSH ML, UYGUN K: Organ reengineering through development of a transplantable recellularized liver graft using decellularized liver matrix. Nat Med 16: 814-820, 2010.

VALENTIN JE, TURNER N J, GILBERT TW, BADYLAK SF: Functional skeletal muscle formation with a biologic scaffold. Biomaterials 31: 7475-7484, 2010.

VANDAEL DH, MARCANTONI A, MAHAPATRA S, CARO A, RUTH P, ZUCCOTTI A, KNIPPER M, CARBONE E: $\mathrm{Ca}_{\mathrm{v}} 1.3$ and BK channels for timing and regulating cell firing. Mol Neurobiol 42: 185-198, 2010.

VIERO C, FOROSTYAK O, SYKOVA E, DAYANITHI G: Getting it right before transplantation: example of a stem cell model with regenerative potential for the CNS. Front Cell Dev Biol 2: 36, 2014.

WANG R, ZHANG L, BOLSTAD J, DIAO N, BROWN C, RUEST L, WELCH W, WILLIAMS AJ, CHEN SRW: Residue Gln4863 within a predicted transmembrane sequence of the $\mathrm{Ca}^{2+}$ release channel (ryanodine receptor) is critical for ryanodine interaction. J Biol Chem 278: 51557-51565, 2003.

ZAMMIT PS, RELAIX F, NAGATA Y, RUIZ AP, COLLINS CA, PARTRIDGE TA, BEAUCHAMP JR: Pax7 and myogenic progression in skeletal muscle satellite cells. J Cell Sci 119: 1824-1832, 2006. 